3 Research Square
Preprints are preliminary reports that have not undergone peer review.

They should not be considered conclusive, used to inform clinical practice, or referenced by the media as validated information.

\title{
Systemic Lupus Erythematosus triggered by SARS-CoV-2 Infection: A Systematic Review Based on a Case Report
}

\author{
Abraham Edgar Gracia-Ramos ( $\nabla$ dr.gracia.dmm@gmail.com ) \\ Department of Internal Medicine, General Hospital, National Medical Center "La Raza”, Instituto Mexicano del Seguro Social https://orcid.org/0000-0003- \\ 1842-2554 \\ Miguel Angel Saavedra-Salinas \\ Department of Rheumatology, Specialities Hospital, National Medical Center "La Raza”, Instituto Mexicano del Seguro Social,
}

Case Report

Keywords: Systemic Lupus Erythematosus, severe acute respiratory syndrome coronavirus 2, Coronavirus, COVID-19

Posted Date: November 11th, 2020

DOI: https://doi.org/10.21203/rs.3.rs-105222/v1

License: (c) (i) This work is licensed under a Creative Commons Attribution 4.0 International License. Read Full License

Version of Record: A version of this preprint was published at Rheumatology International on November 11th, 2020. See the published version at https://doi.org/10.1007/s00296-021-04794-7. 


\section{Abstract}

Systemic lupus erythematosus (SLE) is an autoimmune and multisystemic chronic inflammatory disease that can affect various organs, including skin, joints, kidneys, lungs and the nervous system. Infectious agents have long been implicated in the pathogenesis of SLE. The new viral infection caused by severe acute respiratory syndrome coronavirus 2 (SARS-CoV-2) has shown that, in genetically predisposed patients, could trigger the presentation or exacerbation of autoimmune disease. We herein report a case of a 45-year-old man who presented respiratory symptoms, bilateral pleural effusion, ascites, splenomegaly, severe thrombocytopenia and renal failure with proteinuria and hematuria. SARS-CoV-2 PCR confirmed the COVID-19 diagnosis. We diagnosed the patient with SLE based on the clinical manifestations and positive immunological markers (2019 European League Against Rheumatism/American College of Rheumatology score of 18). Glucocorticoid pulses were administered to the patient with improvement in renal function. However, thrombocytopenia was also refractory to IV immunoglobulin and rituximab, so the patient underwent splenectomy. Through a systematic search of the medical literature, we retrieved 2 cases with SLE new onset and 5 cases with previous SLE diagnosis that shown activity of disease due SARS-CoV-2 infection. We herein present a systemic review of these cases and discuss the clinical manifestations that could help to the diagnosis of this clinical condition.

\section{Introduction}

Systemic lupus erythematosus (SLE) is a potentially fatal, chronic, multisystem autoimmune disorder that affects different steps of the immune cascade resulting in a striking heterogeneity of clinical presentations, including many organs such as the skin, joints, the central nervous system, the kidneys, the hematologic system, among others [1,2]. The natural history of SLE ranges from an insidious slowly progressive disease, with exacerbations and remissions, to an acute and rapidly fatal disease. It is one of the most common autoimmune diseases, especially among Afro-Americans, Hispanic and Asian populations. SLE is more common in women than in men and affects women particularly between puberty and menopause (female/male ratio of 9/1) [1]. The major causes of death include renal disease, severe disease flares with significant organ damage, and infections [3]. The SLE diagnosis is based on the criteria from the more recent 2019 European League Against Rheumatism (EULAR)/American College of Rheumatology (ACR) classification criteria that include positive antinuclear antibody (ANA) at least once as obligatory entry criterion, followed by additive weighted criteria grouped in 7 clinical (constitutional, hematologic, neuropsychiatric, mucocutaneous, serosal, musculoskeletal, renal) and 3 immunologic (antiphospholipid antibodies, complement proteins, SLE-specific antibodies) domains, and weighted from 2 to 10 . Patients accumulating $\geq 10$ points are classified with a sensitivity of $96.1 \%$ and specificity of $93.4 \%$ [4].

The etiology of SLE is unknown, although both exogenous and endogenous factors have been found to influence its pathogenesis, with infectious agents playing an important role in genetically predisposed individuals [5]. Various pathogens have been implicated in the development of SLE, especially viruses such as human endogenous retroviruses, Epstein-Barr virus, parvovirus B19, cytomegalovirus and human immunodeficiency virus type 1 [6]. They may contribute to disease pathogenesis through triggering autoimmunity via structural or functional molecular mimicry, encoding proteins that induce crossreactive immune responses to self-antigens or modulate antigen processing, activation, or apoptosis of B and T cells, macrophages or dendritic cells [6-8]. Coronavirus disease 19 (COVID-19), a newly emerged respiratory disease caused by severe acute respiratory syndrome coronavirus 2 (SARS-CoV-2), has recently become pandemic. The COVID-19 pathophysiology has shown that, in genetically predisposed patients, could lead to the presentation or exacerbations of autoimmune diseases [9]. Hence, we present the case of a patient who developed SLE triggered by a SARS-CoV-2 infection and we also conducted a review of the literature.

\section{Case Report}

A 45-year-old man presented in the emergency department with dry cough, malaise, myalgia, arthralgia, fever and swelling of the legs. The patient's symptoms had started 3-weeks previously with recurrent episodes of fever, dry cough, myalgia and arthralgia, which had worsened in the last week and adding edema of the legs. A general practitioner prescribed azithromycin, acetylsalicylic acid, paracetamol, and oseltamivir 2 weeks after the onset of symptoms. The patient was previously healthy, without a history of drug abuse or a family history of autoimmune diseases. Initial physical examination revealed a body temperature of $37.1^{\circ} \mathrm{C}$, a blood pressure of $116 / 70 \mathrm{mmHg}$, a pulse of 102 beats per minute, and a respiratory rate of 22 breaths per minute. Pulse oximetry showed an oxygen saturation of $92 \%$ in room air. His throat was hyperemic. No abnormalities were detected on auscultation of the lungs and heart. No lymphadenopathy or hepatosplenomegaly were found. He had edema of the lower extremities (1+). Initial laboratory studies showed hyperazotemia (creatinine $2.53 \mathrm{mg} / \mathrm{dL}$ [normal range -NR- 0.7-1.2 mg/L], urea $107.96 \mathrm{mg} / \mathrm{dL}$ [NR 10-50 mg/dL]), hypoalbuminemia ( $2.5 \mathrm{~g} / \mathrm{dL}, \mathrm{NR} 3.4-4.8 \mathrm{~g} / \mathrm{dL})$, thrombocytopenia (13.000/ $\mu \mathrm{L}, \mathrm{NR}$ $150.000-450.000 / \mu \mathrm{L})$, mild anemia $(11.8 \mathrm{~g} / \mathrm{dL}, \mathrm{NR} 14.0-18.0 \mathrm{~g} / \mathrm{dL}$ ), prolonged activated partial thromboplastin time (39.2 seconds, NR $24.0-35 \mathrm{~seconds}$ ) and elevated fibrinogen $(706 \mathrm{mg} / \mathrm{dL}$, NR $200-400 \mathrm{mg} / \mathrm{dL})$. Chest X-ray showed bilateral reticular pattern with vascular enlargement (Figure 1). Abdominal ultrasonography revealed small bilateral pleural effusion, peritoneal fluid and splenomegaly. The SARS-CoV-2 polymerase chain reaction (PCR) with nasopharyngeal swab was positive.

The patient was admitted to the isolation area for COVID-19 patients of the department of Internal Medicine and therapy with dexamethasone 6 mg IV/day, ceftriaxone $1 \mathrm{gr} \mathrm{IV} \mathrm{twice} \mathrm{daily,} \mathrm{furosemide} 20 \mathrm{mg} \mathrm{IV}$ twice daily and paracetamol $1 \mathrm{gr}$ PO was started. Further investigation revealed D-dimer of 3,437 $\mathrm{ng} / \mathrm{mL}$ (NR 0.0-222 ng/mL), C-reactive protein (CRP) of $154.09 \mathrm{mg} / \mathrm{L}$ (NR 0.0-5.0), ferritin level of 1,752.21 ng/mL (NR $17.9-464.0 \mathrm{ng} / \mathrm{mL}$ ), urinalysis with albuminuria $(0.25 \mathrm{~g} / 24 \mathrm{~h})$ and erythrocyturia. Immunologic test showed signs of autoimmune disease, including antinuclear antibodies (ANA) 1:1280 positive antinuclear antibodies with coarse speckled pattern, anti-double-stranded (ds) DNA $23 \mathrm{IU} / \mathrm{mL}$ (negative $<20 \mathrm{IU} / \mathrm{mL}$ ), anti-SSA $83.44 \mathrm{IU} / \mathrm{mL}$ (negative $<20 \mathrm{IU} / \mathrm{mL}$ ), anti-SSB $26.754 \mathrm{IU} / \mathrm{mL}$ (negative <20 IU/mL), complement C3 $71.4 \mathrm{mg} / \mathrm{dL}$ (NR 90-177 mg/dL) and immunoglobulin lgG $1790 \mathrm{mg} / \mathrm{dL}$ (NR $770-1510 \mathrm{mg} / \mathrm{dL}$ ). Serology tests for human immunodeficiency virus (human T-lymphotropic virus-1 and virus-2), hepatitis B virus, hepatitis $\mathrm{C}$ virus and were negative. TORCH profile was positive to anti-rubella IgG antibodies and anti-herpes simples IgG antibodies (Table 1). The clinical and laboratory findings led to the diagnosis of SLE (2019 ACR/EULAR score of 18). 
With the initial treatment, the patient showed improvement in constitutional and respiratory symptoms. However, his renal function worsened (blood urea nitrogen [BUN] $125.42 \mathrm{mg} / \mathrm{dL}$, urea $281.5 \mathrm{mg} / \mathrm{dL}$ ) with persistent severe thrombocytopenia $(<10,000 / \mu \mathrm{L})$ and abnormal liver function tests (serum glutamateoxalate transaminase [SGOT] $66.8 \mathrm{U} / \mathrm{L}$, serum glutamate-pyruvate transaminase [SGTP] $70.9 \mathrm{U} / \mathrm{L}$, alkaline phosphatase $362 \mathrm{U} / \mathrm{L}$, gamma-glutamyl transaminase [GGT] $352 \mathrm{U} / \mathrm{L}$ ). The patient received pulse methylprednisolone therapy ( $1 \mathrm{~g} \mathrm{IV}$ for 5 days) and chloroquine $150 \mathrm{mg} / \mathrm{daily}$ was initiated. After this treatment, kidney and liver function improved markedly. Due to persistent severe thrombocytopenia, the patient was administered IV immunoglobulin (2 $\mathrm{mg} / \mathrm{kg} / \mathrm{for} 4$ days) and rituximab $600 \mathrm{mg}$ (3 doses) without satisfactory response $(<10,000 / \mu \mathrm{L})$. Finally, the patient underwent splenectomy, raising his platelets to $38,000 / \mu \mathrm{L}$ and without evidence of bleeding. The patient was discharged on prednisone $60 \mathrm{mg}$ daily and chloroquine $150 \mathrm{mg}$ daily.

\section{Search strategy}

According to the published guidance on narrative reviews [10], a literature search from December 2019 (when SARS-CoV-2 was first reported) to November 2, 2020 in PubMed and Scopus with MeSH search terms "Lupus Erythematosus, Systemic" and "severe acute respiratory syndrome coronavirus 2" or "Coronavirus" or "COVID-19" was performed. Case reports of patients with SARS-COV-2 infection and diagnosis of SLE (new onset or previous SLE diagnosis) with activity triggered (defined as a measurable increased in disease activity in one or more organ systems involving new or worse clinical signs and symptoms and/or laboratory measurements) were included. Publications without restrictions in the language were eligible for inclusion. We extracted the following data from the selected papers: age, sex, SLE duration, clinical symptomatology, laboratory tests (including immunologic profile), antiviral therapy, SLE therapy, complications and outcome.

\section{Results}

A total of 78 potentially relevant citations were identified. After removing the duplicate citations, title and abstracts of 48 articles were reviewed, and 9 articles relevant to the topic of the review were reviewed to detail. Seven case reports were found to be relevant to this research (Figure 2) [11-17]. With the present report, a total of 8 cases were included for this review. Of the 8 patients (including ours), 6 (75\%) were women with a median age of 48 years (range $18-85$ years) (Table 2). Five cases (63\%) occurred in patients with previous history of SLE (one case with associated antiphospholipid syndrome and another case with end-stage renal disease secondary to WHO Class IV lupus nephritis) $[11,12,14,16,17]$. The nonspecific clinical manifestations reported were fever in 5 cases [12,13,16,17 and present report], malaise in 3 cases [13,17 and present report], 1 case with headache [14] and 1 case with myalgia and arthralgia [present report]). Organ-specific manifestations reported were pulmonary (cough in 4 cases [13,14,17 and present report], shortness of breath in 4 cases [1214], chest discomfort in 1 case [11] and peripheral cyanosis in 1 case [15]), cardiovascular (2 cases with circulatory collapse [13,15]), hematological (hemoptysis in 1 case [16], gingival bleeding in 1 case [11] and 1 case with diffuse purpuric rash [14]) and renal (edema in 2 cases [15 and present report]) features. Laboratory findings included anemia in 3 cases (one with confirmed immune hemolysis) [13,14 and present report], thrombocytopenia in 6 cases (5 with severe thrombocytopenia $[<50.000 / \mu L])[11,13-16$ and present report], lymphopenia in 5 cases $[11-13,15,17]$, hyperazotemia in 4 cases $[13,15,17$ and present report], increased transaminases in 1 case [present report], hyperbilirubinemia in 1 case [14], increased LDH in 4 cases [12,13,15,17], elevated CRP in 6 cases [11,13-15,17 and present report], hyperferritinemia in 4 cases [13,15,17 and present report], prolonged prothrombin time in 1 case [14], prolonged activated partial thromboplastin time in 4 cases $[11,13,14$ and present report], prolonged international normalized ratio in 2 cases [13,16], elevated fibrinogen in 2 cases [14 and present report], elevated D-dimer in 5 cases [12-14,17 and present report], proteinuria in 3 cases [13,15 and present report] and hematuria in 3 cases [13,15 and present report]. Immunological tests showed low serum complement in 5 cases [12-14,17 and present report], high titer of ANA in 4 cases [13,15 and present report], high titers of anti-dsDNA antibodies in 4 cases [12,13,17 and present report], anti-Ro/SSA antibodies in 1 case [present report], positive anti-La/SSB antibodies in 1 case [present report], positive lupus anticoagulant in 3 cases [11,13,14], positive anticardiolipin antibodies in 2 cases $[13,14]$, and positive anti- $\beta 2$-glycoprotein 1 antibodies in 2 cases [13,14]. Reported SLE activity was hematologic in 6 patients [11,13-16 and present case], serosal in 3 patients [13,15 and present case], renal in 3 patients [13,15 and present case] and pulmonary in two patients [13,17]. The diagnosis of SARS-CoV-2 infection was made by PCR test in 7 patients [11-14,16,17] and by serologic test in 1 patient [15]. Imaging studies found bilateral pleural effusion in 3 cases [13,15 and present case], patchy ground-glass opacities in 5 cases (one with chronic interstitial lung fibrosis) [12-14,16,17], bilateral reticular pattern with vascular enlargement in 1 case [present case], pericardial effusion with tamponade in 1 case [13] and impaired left ventricle ejection fraction in 1 case [13]. The treatment used in patients with a previous diagnosis of SLE included hydroxychloroquine-belimumab-azathioprine-warfarin [16]; hydroxychloroquinemycophenolic acid [12,17]; prednisone [11]; and no therapy [14]. Treatment for COVID-19 was administered in 4 patients, remdesivir in 1 case [14], tocilizumab in 1 case [13], lopinavir/ritonavir and ribavirin in 1 case [17] and dexamethasone in 1 case [present report]. On the other hand, SLE activity was treated with glucocorticoids in all cases; IVIg was added in 4/7 patients [11,14,17 and present report]; antimalarial drugs in 3/7 patients [13,16, and present report]; rituximab in 2/7 patients [14 and present report]; plasmapheresis [13] and eltrombopag [16] in one patient each. A patient underwent splenectomy for refractory thrombocytopenia [present report]. Four patients required 3 or more drugs for the management of SLE activity [13,14,16 and present report]. Five patients required supplemental oxygen [12-15,17]; 3 patients developed severe acute respiratory distress syndrome and used invasive ventilation [13,14,17]. One case presented intraventricular hemorrhage due to severe thrombocytopenia [14]; and one case presented multiple deep venous thrombosis (DVT), with heart failure, and kidney failure that warranted hemodialysis [13]. Death was reported in 2 cases (one case with severe acute respiratory distress syndrome, heart failure, kidney injury and multiple DVT [13] and one case with severe acute respiratory distress syndrome and intraventricular hemorrhage [14]).

\section{Discussion}

The diagnosis of activity or new onset SLE is difficult in patients with SARS-CoV-2 infection because both diseases share some characteristics. The spectrum of presentation of COVID-19 ranges from asymptomatic individuals or mild symptoms to severe-critical illness, which is categorized as mild, severe, and critical illness [18]. According to a systematic review that included 148 articles (24,410 patients), the most prevalent constitutional symptoms in patients with confirmed COVID-19 were fever (78\%), fatigue (31\%), myalgia (17\%) and arthralgia (11\%) [19]. In SLE patients, fatigue (80-100\%), arthralgia (90\%), fever (over 
$50 \%$ ) and myalgia are the most prevalent constitutional symptoms [20]. These symptoms are nonspecific, and therefore do not allow any differentiation between these diseases.

Pulmonary manifestations are very common in patients with SLE, with $50 \%$ to $70 \%$ of patients suffering from some form of pulmonary complications during the disease process [21]. However, acute pulmonary pneumonitis is an uncommon (1-2\%) manifestation of SLE (although, in approximately half of the patients with acute lupus pneumonitis, pneumonitis is the first manifestation of SLE) [21,22]. In one case series, the most common presenting symptoms of lupus pneumonitis included fever, cough, dyspnea, hypoxia, and lung crepitations [23]. The main respiratory manifestations of COVID-19 are cough (57\%), dyspnea (23\%) and chest pain (7\%) [19]. Both diseases showed a ground glass appearance by CT [21,24]. Due to these similarities, and given the current pandemic state by SARS-CoV-2, respiratory symptoms should be attributed to COVID-19 unless the patient does not respond to empiric treatment for pneumonia and when extrapulmonary features of SLE are noted (e.g., malar rash, oral ulcers, alopecia, polyserositis, abnormal urine sediment, renal insufficiency, cytopenia, thrombophilia, lymphadenopathy, splenomegaly, joint swelling). In the present review, the respiratory manifestations were attributed to SARS-CoV-2 infection (included the presence of ARDS in 2 patients), except 2 patients diagnosed with lupus pneumonitis in whom this diagnosis was considered only after a lack of response to initial treatment for COVID-19. On the other hand, pleural effusion is uncommon in COVID-19. In a systemic review to explore the chest CT imaging findings in COVID-19 patients that included 55 studies, pleural effusion was reported only in 11\% [24]. Pleuritis is the most common thoracic manifestation of SLE. Clinically apparent pleural effusion has been reported in up to $50 \%$ of patients with SLE and may be found in up to $93 \%$ of cases at necropsy [25]. In the present review, pleural effusion was reported in $37.5 \%$ of cases and its presence was associated to activity of SLE.

The most commonly reported blood count abnormality in SARS-CoV-2 infection is lymphopenia, which occurs in 35\%-83\% of patients [26]. However, lymphopenia is present in 75\% of SLE patients with active disease [27]. Therefore, this finding is not useful for a differential diagnosis between both diseases. Instead, abnormal platelet count should be look with attention. Mild thrombocytopenia (100,000 - 150,000/ $\mu \mathrm{L})$ has been reported in up to $20 \%-36 \%$ of COVID19 cases but severe thrombocytopenia $(<50,000 / \mu \mathrm{L})$ is unusual and it is associated with the severity of the disease [26,28]. In a case series of patients admitted to an intensive care unit (ICU) in Wuhan, a platelet count of $<100,000 / \mu \mathrm{L}$ was observed in only $5 \%$ of patients [29]. Thrombocytopenia $<100,000 / \mu \mathrm{L}$ has been reported in $20 \%$ to $40 \%$ of patients with SLE [30]. In the present series, thrombocytopenia was reported in 6 of 7 patients and was considered severe $(<50,000 / \mu \mathrm{L})$ and refractory to treatment in 5 cases. The possible pathophysiological processes of thrombocytopenia caused by SARS-CoV-2 infection include direct attack to the hematopoietic stem/progenitor cells and damage to the lungs by autoantibodies and immune complexes [31]. We speculate that the autoimmune mechanisms against platelet induced by SARS-CoV-2 may be more severe in a patient genetically predisposed or with history of SLE and therefore manifest as severe and refractory thrombocytopenia.

Renal involvement in COVID-19 patients has been reported in $>20 \%$ of hospitalized patients and in $>50 \%$ of ICU patients [32]. The clinical spectrum can range from the presence of proteinuria and hematuria to acute kidney injury (AKI) requiring renal replacement therapy [33]. Lupus nephritis (LN) is the most common cause of kidney injury in SLE (occurs in 50\%) [34]. The clinical presentation and laboratory findings in LN may differ, ranging from "silent" LN to severe proteinuria and nephrotic syndrome, which can result in AKI. However, patients most commonly present with mild proteinuria and/or hematuria and, in some cases, leukocyturia [35]. Because of these similarities, kidney injury in a patient with suspected SLE activity infected with SARS-CoV-2 can be challenging. In the present series, of the 3 cases that showed kidney disease, in 2 of them the severity of the kidney injury was not consistent with the respiratory disease caused by COVID-19. Therefore, this can be taken into account when making the differential diagnosis.

Glucocorticoids were the first-line treatment for SLE activity in all cases of this series, regardless of the clinical presentation, according to the current guidelines [36]. The treatment with glucocorticoids alone was successful in 2 patients and 4 cases needed three or more drugs to achieve the control of SLE activity. In particular, hematological activity was the main manifestation that showed resistance to initial treatment. Rheumatologists should be aware of this situation in order to act promptly in case of this presentation.

The possible mechanism of autoimmunity following SARS-CoV-2 infection include molecular mimicry (cross-reacting epitope between the virus and the host), bystander killing (virus-specific CD8+T cells migrating to the target tissues and exerting cytotoxicity), epitope spreading, viral persistence (polyclonal activation due to the constant presence of viral antigens driving immune-mediated injury) and formation of neutrophil extracellular traps [37]. In patients hospitalized for SARS-CoV-2 pneumonia a prevalence of ANA of 35.6\% and lupus anticoagulant of $11.1 \%$ has been reported [38]. Other autoantibodies such as anti-Ro/SSA have also been reported [39]. Therefore, this highlights the ability of SARS-CoV-2 to trigger autoimmunity phenomena, which can lead to onset of SLE or a flare.

This review has several limitations owing to its retrospective nature, limited size, and heterogeneity. In addition, the SARS-CoV-2infection is still under study and the spectrum of manifestations that it can cause in patients with a previous or new-onset diagnosis of SLE is still unknown. However, this case series can provide meaningful information regarding the clinical profile, diagnosis and management of this complex situation.

In conclusion, the diagnosis of new onset or flare of SLE in a patient with SARS-CoV-2 infection is a challenge. To our knowledge derived from the present series, the clinical keys that could help with the differential diagnosis are severe thrombocytopenia, serositis and kidney injury that are not related to the degree of respiratory disease. The presence of such findings should lead to the determination of immunological markers to confirm or rule out the presence of SLE. The main objective should be the earliest possible diagnosis of activity of SLE to enable the initiation of prompt specific therapy.

\section{Declarations}

\section{Author contributions}

The case was diagnosed and followed up by AEGR and MASS, and AEGR conceived and planned the case report. Material preparation, data collection and analysis were performed by AEGR and MASS. AEGR wrote the initial draft of the manuscript. MASS revised and edited the manuscript. The final version was 
read, corrected, and approved by both authors and agree to be accountable for all aspects of the work.

\section{Funding}

The authors received no financial support for the research, authorship, and/or publication of this article.

\section{Compliance with ethical standards}

\section{Conflicts of Interest}

The authors declared no conflicts of interest.

\section{Ethical approval}

All procedures performed in studies involving human participants were in accordance with the ethical standards of the institutional and/or national research committee and with the 1964 Helsinki declaration and its later amendments or comparable ethical standards.

\section{Informed consent}

Informed consent for publication has been obtained from the patient, in line with the COPE best practice guidelines.

\section{References}

1. Kaul A, Gordon C, Crow MK, Touma Z, Urowitz MB, van Vollenhoven R, Ruiz-Irastorza G, Hughes G. Systemic lupus erythematosus (2016). Nat Rev Dis Primers 2:16039. https://doi.org/10.1038/nrdp.2016.39.

2. Fava A, Petri M (2019). Systemic lupus erythematosus: Diagnosis and clinical management. J Autoimmun 96:1-13. https://doi.org/10.1016/j.jaut.2018.11.001.

3. Doria A, laccarino L, Ghirardello A, Zampieri S, Arienti S, Sarzi-Puttini P, Atzeni F, Piccoli A, Todesco S (2006). Long-term prognosis and causes of death in systemic lupus erythematosus. Am J Med 119(8):700-6. https://doi.org/10.1016/j.amjmed.2005.11.034.

4. Aringer M, Costenbader K, Daikh D, Brinks R, Mosca M, Ramsey-Goldman R, Smolen JS, Wofsy D, Boumpas DT, Kamen DL, Jayne D, Cervera R, CostedoatChalumeau N, Diamond B, Gladman DD, Hahn B, Hiepe F, Jacobsen S, Khanna D, Lerstrøm K, Massarotti E, McCune J, Ruiz-Irastorza G, Sanchez-Guerrero J, Schneider M, Urowitz M, Bertsias G, Hoyer BF, Leuchten N, Tani C, Tedeschi SK, Touma Z, Schmajuk G, Anic B, Assan F, Chan TM, Clarke AE, Crow MK, Czirják L, Doria A, Graninger W, Halda-Kiss B, Hasni S, Izmirly PM, Jung M, Kumánovics G, Mariette X, Padjen I, Pego-Reigosa JM, Romero-Diaz J, RúaFigueroa Fernández Í, Seror R, Stummvoll GH, Tanaka Y, Tektonidou MG, Vasconcelos C, Vital EM, Wallace DJ, Yavuz S, Meroni PL, Fritzler MJ, Naden R, Dörner T, Johnson SR (2019). 2019 European League Against Rheumatism/American College of Rheumatology Classification Criteria for Systemic Lupus Erythematosus. Arthritis Rheumatol 71(9):1400-1412. https://doi.org/10.1002/art.40930.

5. Illescas-Montes R, Corona-Castro CC, Melguizo-Rodríguez L, Ruiz C, Costela-Ruiz VJ. Infectious processes and systemic lupus erythematosus (2019). Immunology 158(3):153-160. https://doi.org/10.1111/imm.13103.

6. Rigante D, Mazzoni MB, Esposito S. The cryptic interplay between systemic lupus erythematosus and infections (2014). Autoimmun Rev 13(2):96-102. https://doi.org/10.1016/j.autrev.2013.09.004.

7. Francis L, Perl A (2010). Infection in systemic lupus erythematosus: friend or foe? Int J Clin Rheumtol 5(1):59-74. https://doi.org/10.2217/ijr.09.72.

8. Jara LJ, Medina G, Saavedra MA (2018). Autoimmune manifestations of infections. Curr Opin Rheumatol 30(4):373-379. https://doi.org/10.1097/BOR.0000000000000505.

9. Caso F, Costa L, Ruscitti P, Navarini L, Del Puente A, Giacomelli R, Scarpa R (2020). Could Sars-coronavirus-2 trigger autoimmune and/or autoinflammatory mechanisms in genetically predisposed subjects? Autoimmun Rev 19(5):102524. https://doi.org/10.1016/j.autrev.2020.102524.

10. Gasparyan AY, Ayvazyan L, Blackmore H, Kitas GD (2011) Writing a narrative biomedical review: considerations for authors, peer reviewers, and editors. Rheumatol Int 31(11):1409-17. https://doi.org/10.1007/s00296-011-1999-3.

11. Kondo Y, Kaneko Y, Oshige T, Fukui H, Saito S, Okayama M, Kamata H, Ishii M, Hasegawa N, Fukunaga K, Takeuchi T (2020). Exacerbation of immune thrombocytopaenia triggered by COVID-19 in patients with systemic lupus erythematosus. Ann Rheum Dis annrheumdis-2020-218157. https://doi.org/10.1136/annrheumdis-2020-218157.

12. Kichloo A, Aljadah M, Albosta M, Wani F, Singh J, Solanki S (2020). COVID-19 and Acute Lupus Pneumonitis: Diagnostic and Treatment Dilemma. J Investig Med High Impact Case Rep 8:2324709620933438. https://doi.org/10.1177/2324709620933438.

13. Mantovani Cardoso E, Hundal J, Feterman D, Magaldi J (2020). Concomitant new diagnosis of systemic lupus erythematosus and COVID-19 with possible antiphospholipid syndrome. Just a coincidence? A case report and review of intertwining pathophysiology. Clin Rheumatol 39(9):2811-2815. https://doi.org/10.1007/s10067-020-05310-1.

14. Raghavan S, Gonakoti S, Asemota IR, Mba B (2020). A Case of Systemic Lupus Erythematosus Flare Triggered by Severe Coronavirus Disease 2019. J Clin Rheumatol 26(6):234-235. https://doi.org/10.1097/RHU.0000000000001531.

15. Bonometti R, Sacchi MC, Stobbione P, Lauritano EC, Tamiazzo S, Marchegiani A, Novara E, Molinaro E, Benedetti I, Massone L, Bellora A, Boverio R (2020). The first case of systemic lupus erythematosus (SLE) triggered by COVID-19 infection. Eur Rev Med Pharmacol Sci 24(18):9695-9697.

https://doi.org/10.26355/eurrev_202009_23060. 
16. Hayden A, Vyas-Lahar A, Rella V, Rudinskaya A (2020). Severe refractory thrombocytopenia in a woman positive for coronavirus disease 2019 with lupus and antiphospholipid syndrome. Lupus 29(11):1472-1474. https://doi.org/10.1177/0961203320940389.

17. Alharthy A, Faqihi F, Nasim N, Noor A, Akhtar S, Balshi A, Balhamar A, Alqahtani SA, Memish ZA, Karakitsos D (2020). COVID-19 in a patient with a flare of systemic lupus erythematosus: A rare case-report. Respir Med Case Rep 31:101252. https://doi.org/10.1016/j.rmcr.2020.101252

18. Wu Z, McGoogan JM (2020). Characteristics of and Important Lessons From the Coronavirus Disease 2019 (COVID-19) Outbreak in China: Summary of a Report of 72314 Cases From the Chinese Center for Disease Control and Prevention. JAMA 323(13):1239-1242. https://doi.org/10.1001/jama.2020.2648.

19. Grant MC, Geoghegan L, Arbyn M, Mohammed Z, McGuinness L, Clarke EL, Wade RG (2020). The prevalence of symptoms in 24,410 adults infected by the novel coronavirus (SARS-CoV-2; COVID-19): A systematic review and meta-analysis of 148 studies from 9 countries. PLoS One. 15(6):e0234765. https://doi.org/10.1371/journal.pone.0234765.

20. Wallace DJ, Gladman DD (2019). Clinical manifestations and diagnosis of systemic lupus erythematosus in adults. UpToDate. https://www.uptodate.com/contents/clinical-manifestations-and-diagnosis-of-systemic-lupus-erythematosus-in-adults? search=systemic\%20lupus\%20erythematosus\&source=search_result\&selectedTitle=1 150\&usage_type=default\&display_rank=1. Accessed October 25, 2020.

21. Hannah JR, D'Cruz DP (2019). Pulmonary Complications of Systemic Lupus Erythematosus. Semin Respir Crit Care Med 40(2):227-234. https://doi.org/10.1055/s-0039-1685537.

22. Matthay RA, Schwarz MI, Petty TL, Stanford RE, Gupta RC, Sahn SA, Steigerwald JC (1975). Pulmonary manifestations of systemic lupus erythematosus: review of twelve cases of acute lupus pneumonitis. Medicine (Baltimore) 54(5):397-409. https://doi.org/10.1097/00005792-197509000-00003.

23. Wan SA, Teh CL, Jobli AT (2016). Lupus pneumonitis as the initial presentation of systemic lupus erythematosus: case series from a single institution. Lupus 25(13):1485-1490. https://doi.org/10.1177/0961203316646461.

24. Sun Z, Zhang N, Li Y, Xu X (2020). A systematic review of chest imaging findings in COVID-19. Quant Imaging Med Surg 10(5):1058-1079. https://doi.org/10.21037/qims-20-564.

25. Keane MP, Lynch JP 3rd (2000). Pleuropulmonary manifestations of systemic lupus erythematosus. Thorax 55(2):159-66. https://doi.org/10.1136/thorax.55.2.159.

26. Agbuduwe C, Basu S (2020). Haematological manifestations of COVID-19: From cytopenia to coagulopathy. Eur J Haematol https://doi.org/10.1111/ejh.13491.

27. Velo-García A, Castro SG, Isenberg DA (2016). The diagnosis and management of the haematologic manifestations of lupus. J Autoimmun 74:139-160. https://doi.org/10.1016/j.jaut.2016.07.001.

28. Lippi G, Plebani M, Henry BM (2020). Thrombocytopenia is associated with severe coronavirus disease 2019 (COVID-19) infections: A meta-analysis. Clin Chim Acta 506:145-148. https://doi.org/10.1016/j.cca.2020.03.022.

29. Huang C, Wang Y, Li X, Ren L, Zhao J, Hu Y, Zhang L, Fan G, Xu J, Gu X, Cheng Z, Yu T, Xia J, Wei Y, Wu W, Xie X, Yin W, Li H, Liu M, Xiao Y, Gao H, Guo L, Xie J, Wang G, Jiang R, Gao Z, Jin Q, Wang J, Cao B (2020). Clinical features of patients infected with 2019 novel coronavirus in Wuhan, China. Lancet 395(10223):497-506. https://doi.org/10.1016/S0140-6736(20)30183-5.

30. Galanopoulos N, Christoforidou A, Bezirgiannidou Z (2017). Lupus thrombocytopenia: pathogenesis and therapeutic implications. Mediterr J Rheumatol 28(1):20-26. https://doi.org/10.31138/mjr.28.1.20.

31. Zhang Y, Zeng X, Jiao Y, Li Z, Liu Q, Ye J, Yang M (2020). Mechanisms involved in the development of thrombocytopenia in patients with COVID-19. Thromb Res 193:110-115. https://doi.org/10.1016/j.thromres.2020.06.008.

32. Nadim MK, Forni LG, Mehta RL, Connor MJ Jr, Liu KD, Ostermann M, Rimmelé T, Zarbock A, Bell S, Bihorac A, Cantaluppi V, Hoste E, Husain-Syed F, Germain MJ, Goldstein SL, Gupta S, Joannidis M, Kashani K, Koyner JL, Legrand M, Lumlertgul N, Mohan S, Pannu N, Peng Z, Perez-Fernandez XL, Pickkers P, Prowle J, Reis T, Srisawat N, Tolwani A, Vijayan A, Villa G, Yang L, Ronco C, Kellum JA (2020). COVID-19-associated acute kidney injury: consensus report of the 25th Acute Disease Quality Initiative (ADQI) Workgroup. Nat Rev Nephrol https://doi.org/10.1038/s41581-020-00356-5.

33. Hirsch JS, Ng JH, Ross DW, Sharma P, Shah HH, Barnett RL, Hazzan AD, Fishbane S, Jhaveri KD; Northwell COVID-19 Research Consortium; Northwell Nephrology COVID-19 Research Consortium (2020). Acute kidney injury in patients hospitalized with COVID-19. Kidney Int 98(1):209-218. https://doi.org/10.1016/j.kint.2020.05.006.

34. Parikh SV, Almaani S, Brodsky S, Rovin BH (2020). Update on Lupus Nephritis: Core Curriculum 2020. Am J Kidney Dis 76(2):265-281. https://doi.org/10.1053/j.ajkd.2019.10.017.

35. Anders HJ, Saxena R, Zhao MH, Parodis I, Salmon JE, Mohan C (2020). Lupus nephritis. Nat Rev Dis Primers 6(1):7. https://doi.org/10.1038/s41572-0190141-9.

36. Fanouriakis A, Kostopoulou M, Alunno A, Aringer M, Bajema I, Boletis JN, Cervera R, Doria A, Gordon C, Govoni M, Houssiau F, Jayne D, Kouloumas M, Kuhn A, Larsen JL, Lerstrøm K, Moroni G, Mosca M, Schneider M, Smolen JS, Svenungsson E, Tesar V, Tincani A, Troldborg A, van Vollenhoven R, Wenzel J, Bertsias G, Boumpas DT (2019). 2019 update of the EULAR recommendations for the management of systemic lupus erythematosus. Ann Rheum Dis 78(6):736-745. https://doi.org/10.1136/annrheumdis-2019-215089.

37. Shah S, Danda D, Kavadichanda C, Das S, Adarsh MB, Negi VS (2020). Autoimmune and rheumatic musculoskeletal diseases as a consequence of SARSCoV-2 infection and its treatment. Rheumatol Int 40(10):1539-1554. https://doi.org/10.1007/s00296-020-04639-9.

38. Gazzaruso C, Carlo Stella N, Mariani G, Nai C, Coppola A, Naldani D, Gallotti P (2020). High prevalence of antinuclear antibodies and lupus anticoagulant in patients hospitalized for SARS-CoV2 pneumonia. Clin Rheumatol 39(7):2095-2097. https://doi.org/10.1007/s10067-020-05180-7. 
39. Fujii H, Tsuji T, Yuba T, Tanaka S, Suga Y, Matsuyama A, Omura A, Shiotsu S, Takumi C, Ono S, Horiguchi M, Hiraoka N (2020). High levels of anti-SSA/Ro antibodies in COVID-19 patients with severe respiratory failure: a case-based review: High levels of anti-SSA/Ro antibodies in COVID-19. Clin Rheumatol 39(11):3171-3175. https://doi.org/10.1007/s10067-020-05359-y.

\section{Tables}




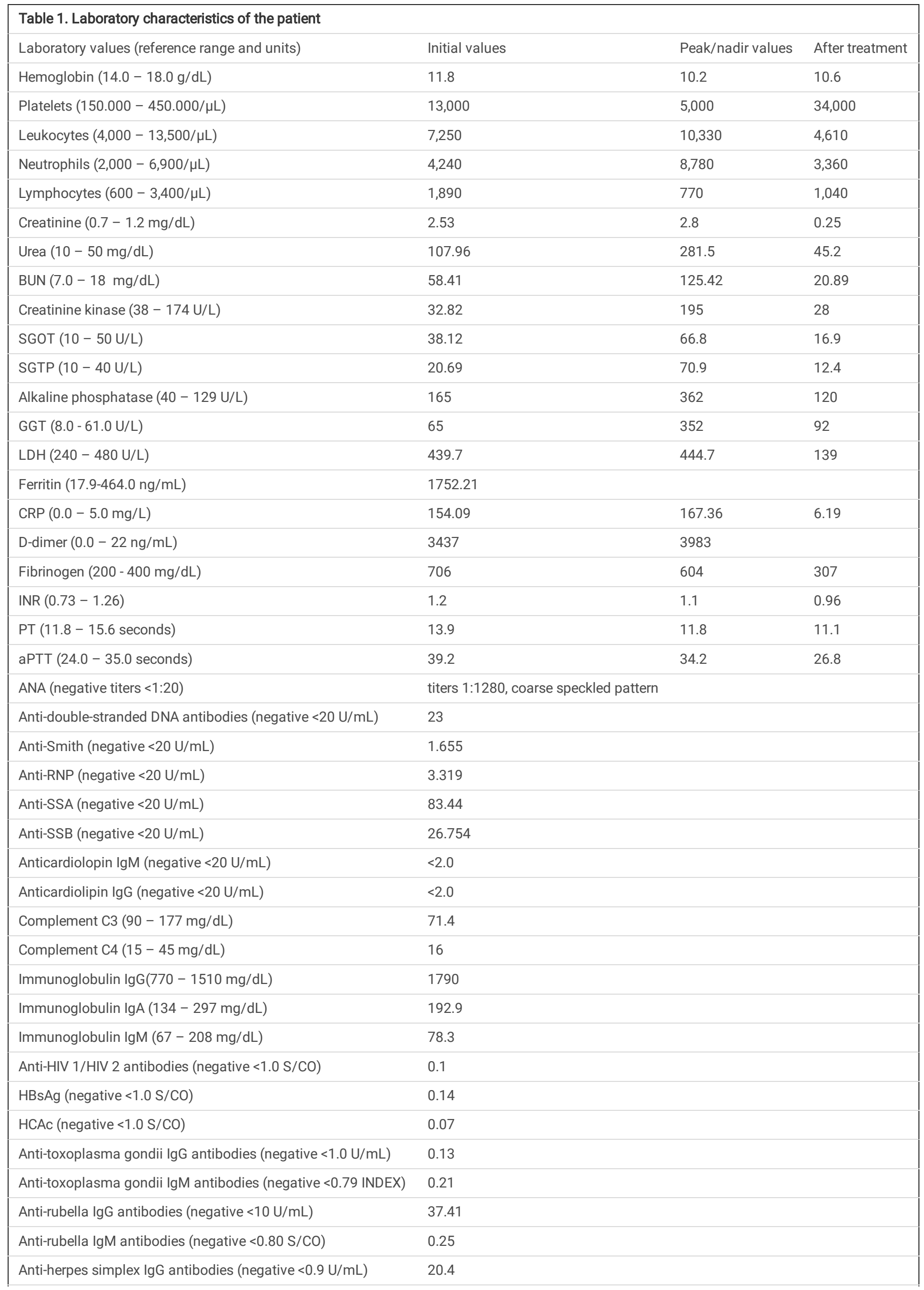

Page 8/13 


\begin{tabular}{|ll|}
\hline Anti-herpes simplex IgM antibodies (negative $<1.0 \mathrm{~S} / \mathrm{CO}$ ) & 0.6 \\
\hline Anti-cytomegalovirus IgG antibodies (negative $<0.5 \mathrm{U} / \mathrm{mL}$ ) & 201.5 \\
\hline Anti-cytomegalovirus IgM antibodies (negative $<0.69$ INDEX) & 0.178 \\
\hline Urine albumin (negative, g/24 H) & 0.25 \\
\hline Urine hemoglobin (negative, $\mathrm{mg} / \mathrm{dL}$ ) & 250 \\
\hline
\end{tabular}

Abbreviations: aTTPactivated partical thromboplastin time; ANA antinuclear antibodies; $A n t i-d s D N A$ anti double stranded deoxyribonucleic acid antibodies, Anti-RNP anti-ribonucleoprotein; BUN blood urea nitrogen; CRP C-reactive protein; GGT gamma-glutamyl transaminase; $H B s A g$ hepatitis B surface antigen; HCAc hepatitis $\mathrm{C}$ antibody; HIV human immunodeficiency virus; $L D H$ lactate dehydrogenase; $P T$ prothrombine time; SGOT serum glutamate-oxalate transaminase; SGTP serum glutamate-pyruvate transaminase 


\begin{tabular}{|c|c|c|c|c|c|c|c|c|}
\hline $\begin{array}{l}\text { First } \\
\text { author of } \\
\text { study }\end{array}$ & Age/Sex & $\begin{array}{l}\text { Time onset } \\
\text { of SLE }\end{array}$ & $\begin{array}{l}\text { Clinical } \\
\text { manifestations }\end{array}$ & $\begin{array}{l}\text { Relevant laboratory } \\
\text { findings }\end{array}$ & $\begin{array}{l}\text { Immunological } \\
\text { test }\end{array}$ & $\begin{array}{l}\text { Imaging } \\
\text { finding }\end{array}$ & $\begin{array}{l}\text { Specific } \\
\text { activity of } \\
\text { SLE }\end{array}$ & $\begin{array}{l}\text { Treatment to SLE } \\
\text { activity }\end{array}$ \\
\hline Kondo [11] & $58 / F$ & $20 \mathrm{yr}$ & $\begin{array}{l}\text { Chest } \\
\text { discomfort, } \\
\text { gingival } \\
\text { bleeding }\end{array}$ & $\begin{array}{l}\text { Lymphopenia (650/ } \\
\mu \mathrm{L}) \\
\uparrow \mathrm{CRP}(0.5 \mathrm{mg} / \mathrm{dL}) \\
\text { Thrombocytopaenia } \\
(5,000 / \mu \mathrm{L}) \\
\uparrow \text { aTTP }(41.3 \mathrm{~s})\end{array}$ & $\begin{array}{l}\text { Lupus } \\
\text { anticoagulant } \\
(+)\end{array}$ & $\begin{array}{l}\text { CT: Patchy } \\
\text { ground-glass } \\
\text { opacities in } \\
\text { both lungs }\end{array}$ & Hematologic & $\begin{array}{l}\text { Prednisone (10 } \\
\text { mg/day) } \\
\text { IVlg }(20 \mathrm{~g} \text { doses x } 5 \\
\text { days) }\end{array}$ \\
\hline $\begin{array}{l}\text { Kichloo } \\
\text { [12] }\end{array}$ & $22 / F$ & $\begin{array}{l}\text { Previous } \\
\text { diagnosis } \\
\text { (unspecified } \\
\text { time) }\end{array}$ & $\begin{array}{l}\text { Fever, } \\
\text { shortness of } \\
\text { breath }\end{array}$ & $\begin{array}{l}\text { Lymphopenia, } \uparrow \text { D- } \\
\text { dimer, } \uparrow \text { LDH }\end{array}$ & $\begin{array}{l}\uparrow \text { anti-dsDNA } \\
(19 \mathrm{IU} / \mathrm{mL}), \downarrow \\
\mathrm{C} 3(84 \\
\mathrm{mg} / \mathrm{dL}), \downarrow \mathrm{C} 4 \\
(9 \mathrm{mg} / \mathrm{dL})\end{array}$ & $\begin{array}{l}\text { CT: Ground } \\
\text { glass } \\
\text { opacities with } \\
\text { chronic } \\
\text { interstitial } \\
\text { lung fibrosis }\end{array}$ & Pulmonary & $\begin{array}{l}\text { Methylprednisolon } € \\
\text { (60 mg } 3 \text { times } \\
\text { daily } 5 \text { days) }\end{array}$ \\
\hline $\begin{array}{l}\text { Mantovani- } \\
\text { Cardoso } \\
\text { [13] }\end{array}$ & $18 / F$ & New-onset & $\begin{array}{l}\text { Productive } \\
\text { cough, } \\
\text { shortness of } \\
\text { breath, fever, } \\
\text { malaise, } \\
\text { tachycardia, } \\
\text { hypotension }\end{array}$ & $\begin{array}{l}\uparrow \mathrm{SCr}(4.6 \mathrm{mg} / \mathrm{dL}), \\
\uparrow \mathrm{BUN}(82 \mathrm{mg} / \mathrm{dL}), \\
\text { anemia }(5.4 \mathrm{~g} / \mathrm{dL}), \\
\text { leucocytosis } \\
(38,600 / \mu \mathrm{L}), \\
\text { lymphopenia } \\
(0.300 / \mu \mathrm{L}), \\
\text { thrombocytopenia } \\
(32,000 / \mu \mathrm{L}), \uparrow \\
\text { ferritin }(2112 \mu \mathrm{g} / \mathrm{L}), \\
\uparrow \mathrm{LDH}(805 \mathrm{U} / \mathrm{L}), \uparrow \\
\mathrm{CPR}(3.73 \mathrm{mg} / \mathrm{dL}), \\
\uparrow \mathrm{ESR}(38 \mathrm{~mm} / \mathrm{h}), \uparrow \\
\mathrm{D}-\mathrm{dimer}(2443 \\
\text { ng/mL), } \uparrow \mathrm{NR}(1.7), \\
\uparrow \text { aPTT }(54 \mathrm{~s}), \text { urine } \\
\text { hemoglobin }(+), \\
\text { urine protein/Cr } \\
\text { ratio } 2.84\end{array}$ & $\begin{array}{l}\text { ANA (+, } \\
\text { >=1:2560, } \\
\text { homogeneous } \\
\text { pattern), Anti- } \\
\text { dsDNA (+, } 943 \\
\text { IU/mL), } \\
\text { Antihistone } \\
(+), \perp C 3(29 \\
\mathrm{mg} / \mathrm{dL}), \perp \mathrm{C} 4 \\
(9 \mathrm{mg} / \mathrm{dL}) \text {, } \\
\text { Anticardiolipin } \\
\text { IgA }(+, 12.1 \\
\text { U/mL, lupus } \\
\text { anticoagulant } \\
(+), \text { beta-2- } \\
\text { microglobulin } \\
(+)\end{array}$ & $\begin{array}{l}\text { Point-of- care } \\
\text { US: } \\
\text { Pericardial } \\
\text { effusion with } \\
\text { tamponade } \\
\text { Rx: Multifocal } \\
\text { airspace } \\
\text { consolidation, } \\
\text { bilateral } \\
\text { pleural } \\
\text { effusions. } \\
\text { ECHO: LVEF } \\
\text { 20-25\% with } \\
\text { left ventricle } \\
\text { dilatation }\end{array}$ & $\begin{array}{l}\text { Serosal } \\
\text { Hematologic } \\
\text { Renal }\end{array}$ & $\begin{array}{l}\text { Pulse steroids, } \\
\text { hydroxychloroquin } € \\
\text { plasmapheresis, } \\
\text { tocilizumab }\end{array}$ \\
\hline $\begin{array}{l}\text { Raghavan } \\
\text { [14] }\end{array}$ & $62 / \mathrm{M}$ & $3 w k$ & $\begin{array}{l}\text { Cough, } \\
\text { shortness of } \\
\text { breath, } \\
\text { headache, } \\
\text { diffuse } \\
\text { purpuric rash }\end{array}$ & $\begin{array}{l}\text { Anemia }(9.1 \mathrm{~g} / \mathrm{dL} \text {, } \\
\text { immune-mediated } \\
\text { hemolysis), } \\
\text { thrombocytopenia } \\
(2000 / \mu \mathrm{L}) \text {, indirect } \\
\text { hyperbilirubinemia } \\
(2.9 \mathrm{mg} / \mathrm{dL}), \uparrow \mathrm{PT} \\
(15.4 \mathrm{~s}), \uparrow \mathrm{aPTT} \\
(41.8 \mathrm{~s}), \uparrow \mathrm{fibrinogen} \\
(561 \mathrm{mg} / \mathrm{dL}), \uparrow \mathrm{D}- \\
\text { dimer, } \uparrow \mathrm{CRP}(11.9 \\
\mathrm{mg} / \mathrm{dL})\end{array}$ & $\begin{array}{l}\text { Lupus } \\
\text { anticoagulant } \\
(+), \\
\text { anticardiolipin } \\
(+) \text {, anti-beta2- } \\
\text { glycoprotein } \\
(+)\end{array}$ & $\begin{array}{l}\text { Rx: Bilateral } \\
\text { patchy } \\
\text { airspace } \\
\text { opacities. }\end{array}$ & Hematologic & $\begin{array}{l}\text { Dexamethasone ( } 4 \text { ( } \\
\mathrm{mg} \text { daily } \mathrm{x} 4 \text { days), } \\
\text { IVlg }(1 \mathrm{mg} / \mathrm{kg} \text { daily } \\
\text { x } 5 \text { days })\end{array}$ \\
\hline $\begin{array}{l}\text { Bonometti } \\
\text { [15] }\end{array}$ & $85 / F$ & New-onset & $\begin{array}{l}\text { Severe } \\
\text { hypotension, } \\
\text { diffuse } \\
\text { dyscrasic } \\
\text { edemas, } \\
\text { peripheral } \\
\text { cyanosis }\end{array}$ & $\begin{array}{l}\text { Leukocytosis, } \\
\text { lymphopenia, } \\
\text { thrombocytopenia, } \\
\text { acute kidney injury, } \\
\uparrow \mathrm{CRP}, \uparrow \text { ferritin, } \uparrow \\
\mathrm{LDH} \text {, proteinuria, } \\
\text { hematuria }\end{array}$ & $\begin{array}{l}\text { ANA (+, } 1: 320 \\
\text { homogeneous } \\
\text { pattern), } \downarrow \\
\text { complement }\end{array}$ & $\begin{array}{l}\text { Rx: Pleural } \\
\text { effusion }\end{array}$ & $\begin{array}{l}\text { Serosal } \\
\text { Hematologic } \\
\text { Renal }\end{array}$ & Steroids \\
\hline $\begin{array}{l}\text { Hayden } \\
\text { [16] }\end{array}$ & $51 / F$ & $18 \mathrm{yr}$ & $\begin{array}{l}\text { Fever, } \\
\text { hemoptysis }\end{array}$ & $\begin{array}{l}\text { Thrombocitopenia } \\
(<10,000 / \mu \mathrm{L}), \uparrow \text { INR } \\
(1.94)\end{array}$ & ND & $\begin{array}{l}\text { CT: Ground } \\
\text { glass } \\
\text { opacities in } \\
\text { the left lower } \\
\text { lobe }\end{array}$ & Hematologic & $\begin{array}{l}\text { Hydroxychloroquin } \\
(300 \mathrm{mg} \text { daily), IVlg } \\
\text { (total of } 2 \mathrm{~g} / \mathrm{kg} \\
\text { body weight), } \\
\text { prednisone }(60 \mathrm{mg} \\
\text { daily), eltrombopag } \\
(50 \mathrm{mg})\end{array}$ \\
\hline $\begin{array}{l}\text { Altharthy } \\
\text { [17] }\end{array}$ & $28 / F$ & $\begin{array}{l}\text { Previous } \\
\text { diagnosis } \\
\text { (unspecified } \\
\text { time) }\end{array}$ & $\begin{array}{l}\text { Fever, cough, } \\
\text { fatigue, } \\
\text { dyspnea }\end{array}$ & $\begin{array}{l}\text { Lymphopenia (590/ } \\
\mu \mathrm{L}), \uparrow \mathrm{CRP}(354 \\
\mathrm{mg} / \mathrm{L}), \uparrow \mathrm{D} \text {-dimer } \\
(1.9 \mathrm{mcg} / \mathrm{ml}), \uparrow \mathrm{DH} \\
(737 \mathrm{U} / \mathrm{L}), \uparrow \text { ferritin } \\
(1,126 \mathrm{ng} / \mathrm{ml})\end{array}$ & $\begin{array}{l}\text { Tanti-dsDNA } \\
(22 \mathrm{U} / \mathrm{ml}), \downarrow \text { C3 } \\
(64 \mathrm{mg} / \mathrm{dl}), \downarrow \\
\text { C4 (6 mg/dL) }\end{array}$ & $\begin{array}{l}\text { CT: Bilateral } \\
\text { ground-glass } \\
\text { opacities in } \\
\text { both } \\
\text { lung }\end{array}$ & Pulmonary & $\begin{array}{l}\text { Pulse } \\
\text { methylprednisolon } € \\
\text { therapy }(1 \mathrm{~g} / \text { day IV } \\
\text { x three days }\end{array}$ \\
\hline $\begin{array}{l}\text { Current } \\
\text { case }\end{array}$ & $45 / \mathrm{M}$ & New-onset & $\begin{array}{l}\text { Fever, dry } \\
\text { cough, } \\
\text { myalgia and } \\
\text { arthralgia, } \\
\text { edema of the } \\
\text { legs }\end{array}$ & $\begin{array}{l}\text { Anemia }(10.2 \mathrm{~g} / \mathrm{dL}) \text {, } \\
\text { thrombocytopenia } \\
(5,000 / \mu \mathrm{L}), \uparrow \mathrm{SCr} \\
2.8 \mathrm{mg} / \mathrm{dL}), \uparrow \text { urea } \\
(281.5 \mathrm{mg} / \mathrm{dL}), \uparrow \\
\text { SGOT }(66.8 \mathrm{U} / \mathrm{L}), \uparrow \\
\text { SGTP }(70.9 \mathrm{U} / \mathrm{L}), \uparrow \\
\text { AP }(362 \mathrm{U} / \mathrm{L}), \uparrow \\
\text { GGT } 352, \uparrow \text { ferritin }\end{array}$ & $\begin{array}{l}\text { ANA }(+, 1: 1280 \\
\text { coarse } \\
\text { speckled } \\
\text { pattern), anti- } \\
\text { dsDNA (+, 23 } \\
/ \mathrm{mL}) \text {, anti-RNP } \\
(+, 3.319 \\
\text { U/mL), anti- } \\
\text { SSA }(+, 83.44\end{array}$ & $\begin{array}{l}\text { Rx: Bilateral } \\
\text { reticular } \\
\text { pattern with } \\
\text { vascular } \\
\text { enlargement } \\
\text { Abdominal } \\
\text { US: Bilateral } \\
\text { pleural }\end{array}$ & $\begin{array}{l}\text { Serosal } \\
\text { Hematologic } \\
\text { Renal }\end{array}$ & $\begin{array}{l}\text { Methylprednisolone } \\
\text { ( } 1 \mathrm{~g} \text { x } 5 \text { days), } \\
\text { chloroquine (150 } \\
\text { mg daily), IVlg ( } 2 \\
\mathrm{~g} / \mathrm{kg} / \mathrm{body} \text { weight x } \\
4 \text { days), rituximab } \\
\text { ( } 600 \mathrm{mg}, 3 \text { doses), } \\
\text { splenectomy }\end{array}$ \\
\hline
\end{tabular}




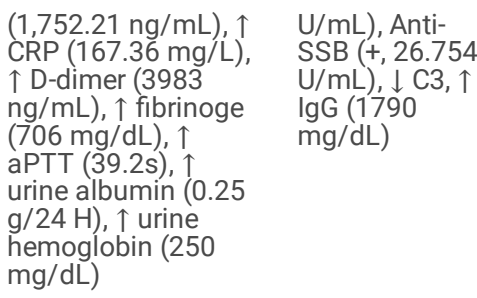

Abbreviations: aTTP activated partical thromboplastin time; $A P$ alkaline phosphatase; $A N A$ antinuclear antibodies; Anti-dsDNA anti double stranded deoxyribonucleic acid antibodies, $A n t i-R N P$ anti-ribonucleoprotein; $A R D S$ acute severe respiratory distress syndrome; $B U N$ blood urea nitrogen; $C R P C$-reactive protein; $C T$ computed tomography; $E C H O$ echocardiography; ERS erythrocyte sedimentation rate; F female; GGT gamma-glutamyl transaminase; IVIg intravenous immunoglobulin; $L D H$ lactate dehydrogenase; $L V E F$ left ventricular ejection fraction; $M$ male; ND not documented; $P T$ prothrombine time; $S C r$ serum creatinine; SGOT serum glutamate-oxalate transaminase; SGTP serum glutamate-pyruvate transaminase; US ultrasound; $R x$ chest X-ray; $w k$ weeks; $y r$ years

\section{Figures}

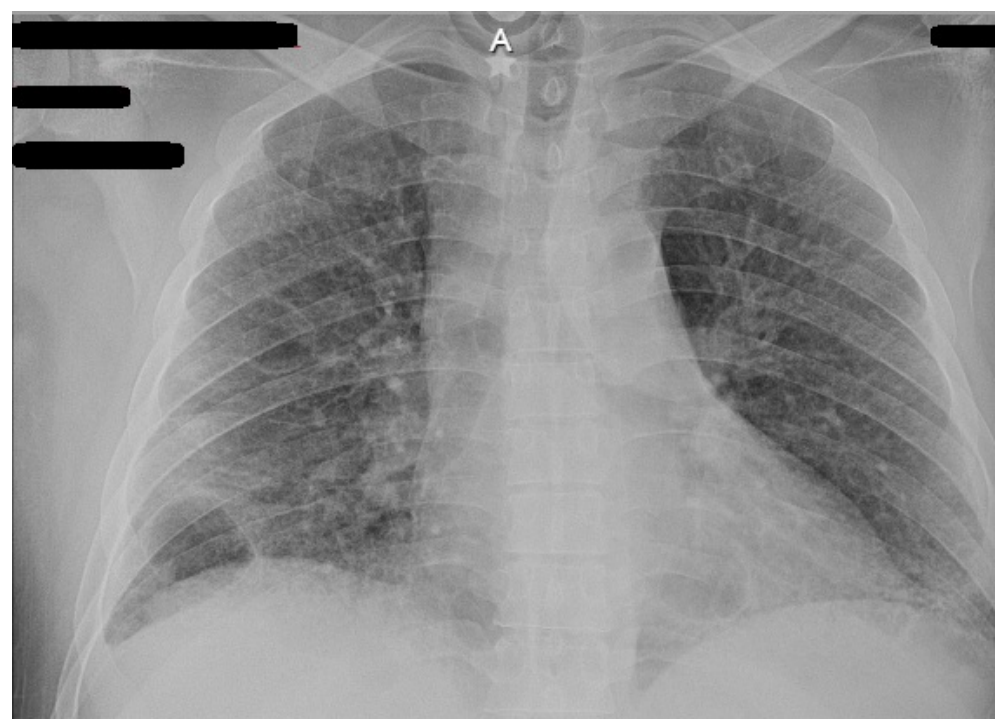

\section{Figure 1}

Chest X-ray showed bilateral reticular pattern with vascular enlargement.

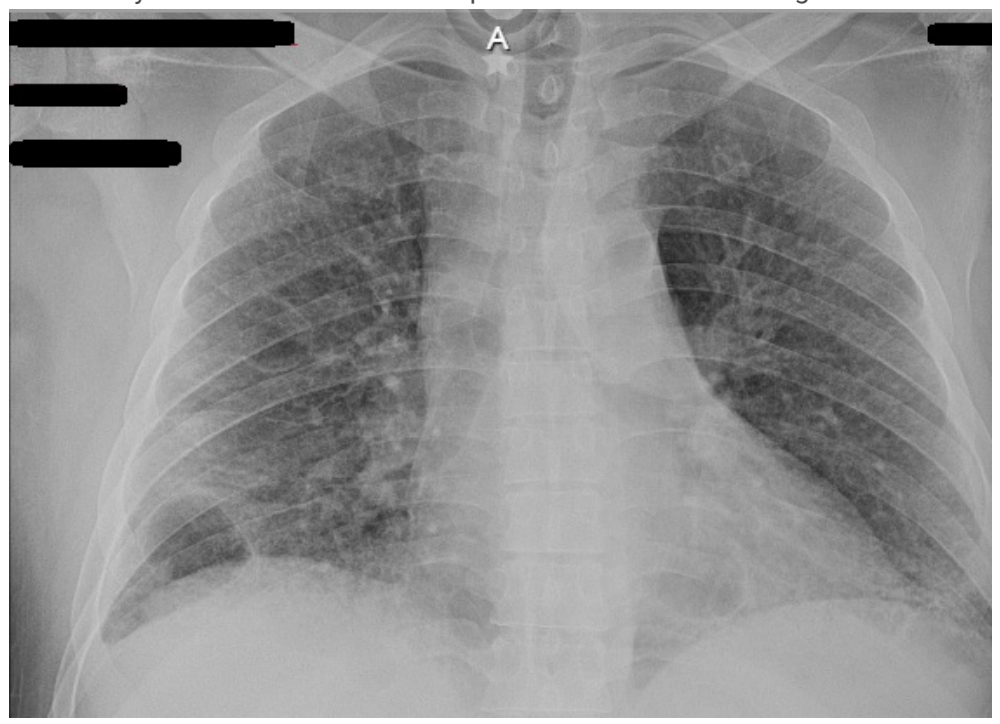

\section{Figure 1}

Chest X-ray showed bilateral reticular pattern with vascular enlargement. 


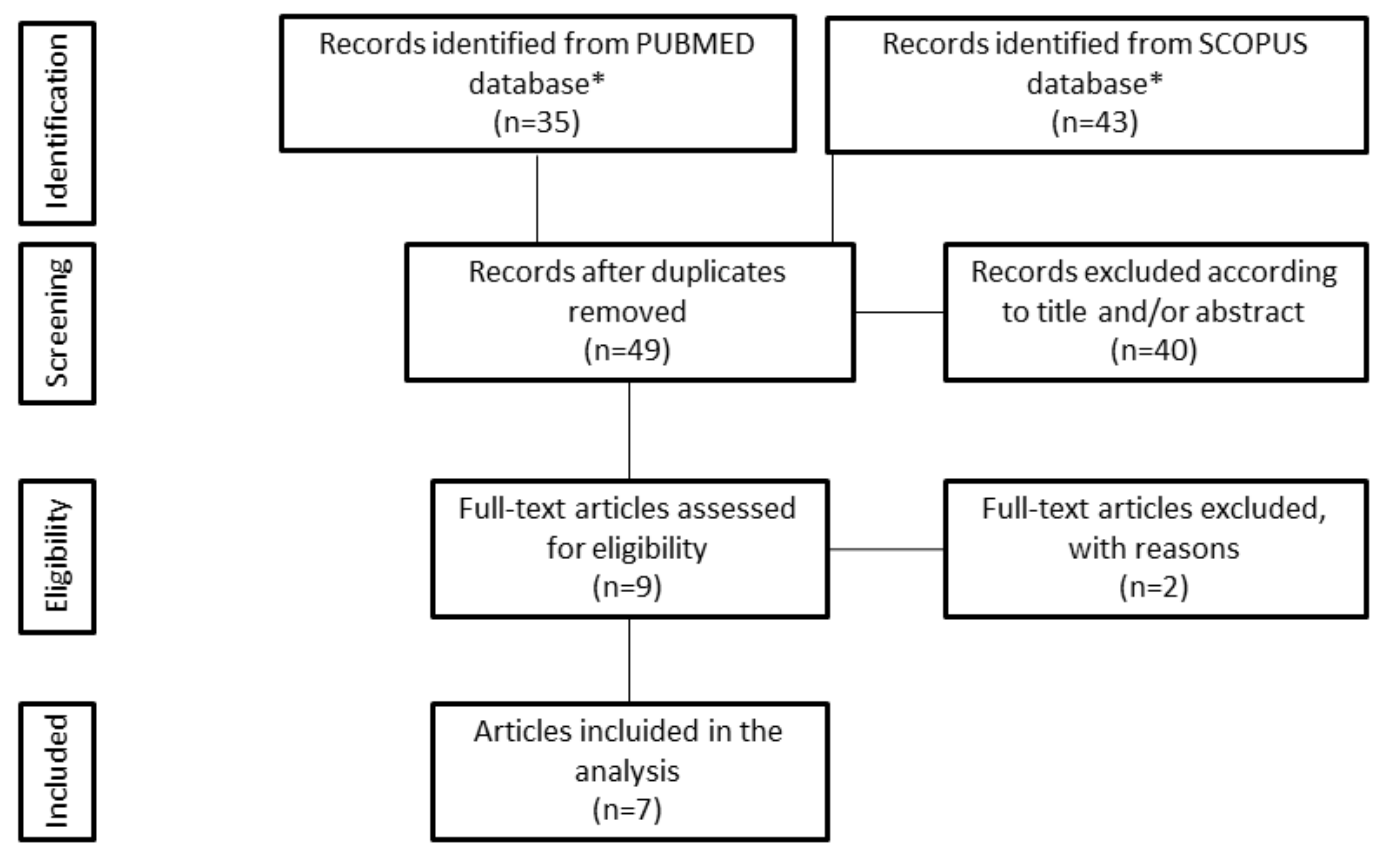

* The MeSH research terms used in search strategy: "Lupus Erythematosus, Systemic", "severe acute respiratory syndrome coronavirus 2", "Coronavirus", "COVID-19".

Figure 2

Flow chart of study selection. 


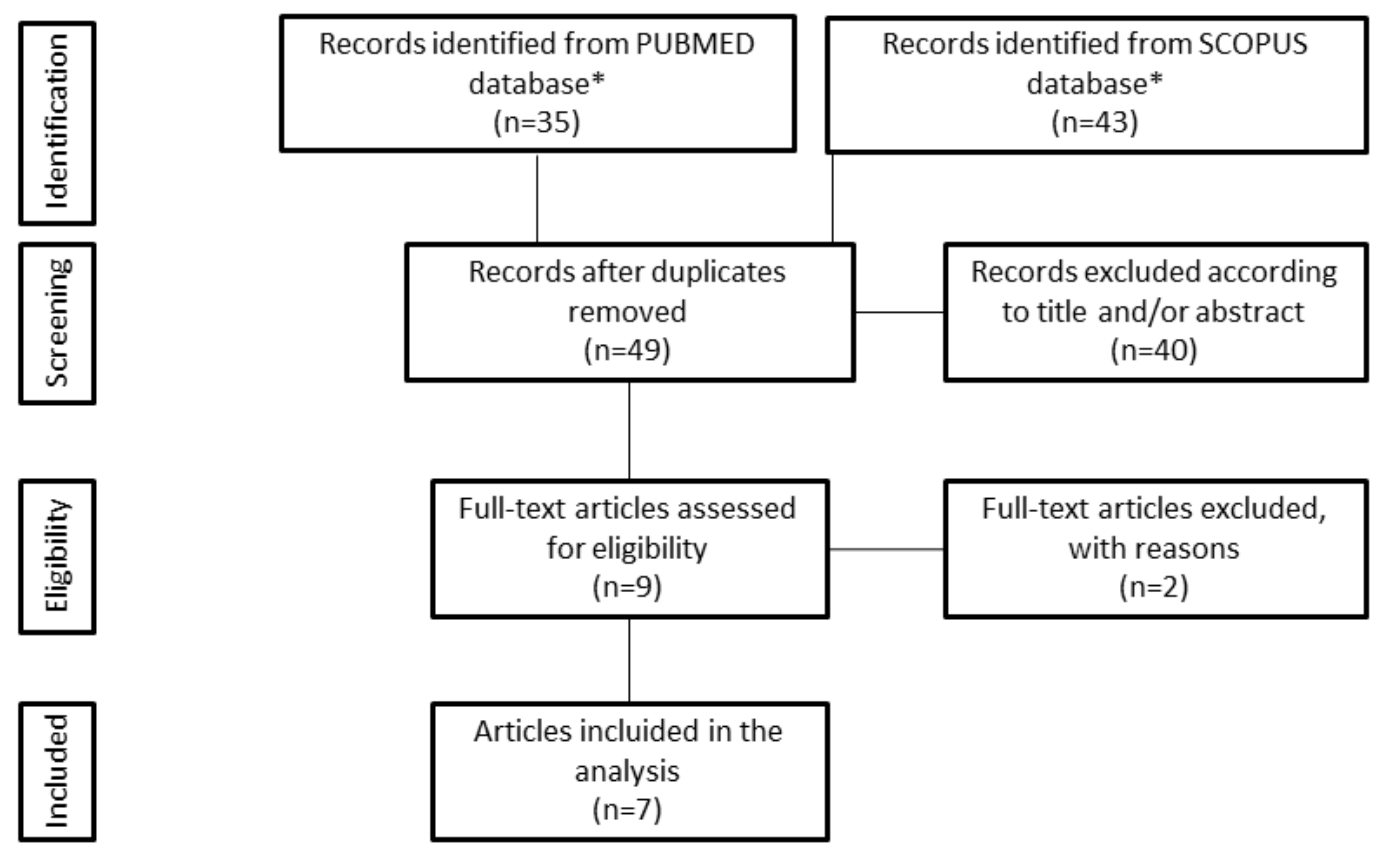

* The MeSH research terms used in search strategy: "Lupus Erythematosus, Systemic", "severe acute respiratory syndrome coronavirus 2", "Coronavirus", "COVID-19".

Figure 2

Flow chart of study selection. 